PAWEE NIZIOŁEK

Instytut Pamięci Narodowej Oddział w Białymstoku

\title{
GENEZA KRYZYSU MONETARNEGO W RZECZYPOSPOLITEJ W DRUGIEJ POŁOWIE XVII W. W OPINII SZLACHTY WOJEWÓDZTWA KRAKOWSKIEGO
}

Badania nad poglądami monetarnymi ${ }^{1}$ społeczeństwa nowożytnej Polski, ze szczególnym uwzględnieniem XVII w., prowadzone są przez historyków oraz ekonomistów już od bez mała stulecia. U zarania XX w. jako jeden z pierwszych tematyką zają się Adam Szelągowski ${ }^{2}$. Wkrótce po nim pracę poświęcona stricte temu zagadnieniu (w XVII w.) przedstawił opinii galicyjskiego środowiska naukowego Zygmunt Gargas ${ }^{3}$. Szczególnie ważna pozycją było opublikowane tuż przed wybuchem II wojny światowej dzieło Romana Rybarskiego, które, choć w swych szerokich ramach tematycznych omawiało w zasadzie całość centralnej skarbowości Rzeczypospolitej drugiej połowy XVII w., stało się bodajże najbardziej opiniotwórczym opracowaniem właśnie $\mathrm{w}$ dziedzinie poglądów monetarnych polskiej szlachty ${ }^{4}$. W powojennej już Polsce kwestią tą zajmowali się m.in.: Edward Lipiński ${ }^{5}$, Jan

${ }^{1}$ „Poglądy monetarne” to pojęcie o dużej złożoności, oznacza ono równocześnie poglądy (w naszym przypadku szlachty) na politykę mennicza, czyli emisyjna, państwa (szczególnie stopę mennicza, ale i ilość pieniądza, jaką należy wprowadzić na rynek oraz jego nominały, itp.), jak również na kwestie regulacji obiegu pieniądza (wzajemny kurs monet różnych kategorii: złote - srebrne - miedziane, krajowe - zagraniczne; ceny kruszców w monecie o narzuconym, sztucznym kursie, itp.) oraz kwestię fałszerstw monetarnych. Stosujacc inny podział, dobrze pasujacy do charakteru źródła, jakim są „akta sejmikowe”, możemy również wyodrębnić spośród „poglądów monetarnych” opinie na temat: przyczyn zaistniałego na rynku pieniężnym stanu rzeczy (z reguły negatywnego, czyli kryzysu), skutków owego stanu, osób lub instytucji odpowiedzialnych za jego zaistnienie oraz środków umożliwiających zaradzenie patologii.

${ }^{2}$ A. Szelagowski, Pieniadz i przewrót cen w XVI i XVII wieku, Lwów 1902.

${ }^{3}$ Z. Gargas, Poglady ekonomiczne w Polsce $w$ XVII wieku, Lwów 1903.

${ }^{4}$ R. Rybarski, Skarb i pieniadz za Jana Kazimierza, Michała Korybuta i Jana III, Warszawa 1939.

${ }^{5}$ E. Lipiński, Studia nad historia polskiej myśli ekonomicznej, Warszawa 1956. 
Czarkowski $^{6}$, Zdzisław Sadowski ${ }^{7}$, Maria Bogucka ${ }^{8}$ i Aleksandra Popioł-Szymańska9 ${ }^{9}$ a ostatnio Bartosz Dziewanowski-Stefańczyk ${ }^{10}$.

Przeważająca część badaczy publikujących dotychczas prace poświęcone poglądom monetarnym w Polsce wieków minionych w pierwszym rzędzie skupiała się na analizie dzieł rodzimych teoretyków tworzacych w epoce. Takie podejście nie stwarzało możliwości zapoznania się z opiniami na temat monetarnej polityki państwa faktycznie będącymi w obiegu społecznym. Roman Rybarski był pierwszym polskim ekonomista-historykiem, który postawił pytanie o poglądy na kwestie mennicze oraz obiegu pieniądza politycznie uprzywilejowanej i szerokiej grupy, jaką była szlachta ${ }^{11}$. Jego spojrzenie na interesujacy nas temat, choć wiek temu miało charakter przełomowy, dziś straciło już znacznie na aktualności, a część postawionych przezeń tez nie może się utrzymać pod ciężarem krytyki opartej na analizie źródeł. Praca ta przyczyniła się też wydatnie do negatywnej stereotypizacji poglądów monetarnych polskiej szlachty w XVII w. Najważniejszą pozycją spośród najnowszych publikacji w omawianej dziedzinie jest praca Aleksandry Popioł-Szymańskiej ${ }^{12}$. Autorka, podejmujac się trudnego zadania stworzenia monografii poglądów monetarnych $\mathrm{w}$ Polsce na przestrzeni od XV do XVIII w., nie ustrzegła się powtórzenia i utrwalenia nietrafnych tez zaprezentowanych wcześniej przez Zygmunta Gargasa czy Romana Rybarskiego, a także postawiła szereg hipotez skłaniających do polemiki. Niewątpliwie istotna praca jest także dysertacja doktorska Bartosza Dziewanowskiego-Stefańczyka poświęcona dyskursowi sejmowemu nad polityką monetarną Rzeczypospolitej w latach 1658-1668, w której autor porusza, choć na marginesie, zagadnienia poglądów monetarnych szlachty ${ }^{13}$.

\footnotetext{
${ }^{6}$ J. Czarkowski, Zarys dziejów myśli ekonomicznej w Polsce, Kraków 1948.

${ }^{7}$ Z. Sadowski, Pieniadz a poczatki upadku Rzeczypospolitej $w$ XVII w., Warszawa 1964.

${ }^{8}$ M. Bogucka, Kryzys monetarny XVII w. Konsekwencje społeczne i psychologiczne $w$ Polsce, „Roczniki Dziejów Społecznych i Gospodarczych” 37, 1976, s. 87-102.

${ }_{9}^{9}$ A. Popioł-Szymańska, Poglady monetarne w Polsce od XV do XVIII wieku, Poznań 1978.

${ }^{10}$ B. Dziewanowski-Stefańczyk, Tytus Liwiusz Burattini jako dzierżawca mennic - ofiara czy winowajca kryzysu lat 1659-1668?, „Barok. Historia - literatura - sztuka” 33, 2010, nr 1, s. 67-96; tenże, Polityka monetarna za panowania Jana Kazimierza. Dyskurs sejmowy wlatach 1658-1668, mps pracy doktorskiejnapisanejpodkier. U.Augustyniak, Warszawa 2012, Wydział Historyczny UW.

${ }^{11}$ Z. Gargas, dz. cyt.

${ }^{12}$ A. Popioł-Szymańska, dz. cyt.

${ }^{13}$ B. Dziewanowski-Stefańczyk, Polityka monetarna...
} 
Niniejszy tekst w żadnej mierze nie może aspirować do miana opracowania odnoszącego się do wszystkich obecnych dotychczas w nauce nieścisłości $\mathrm{w}$ dziedzinie poglądów monetarnych polskiej szlachty w XVII w. Poświęcony jest jedynie niewielkiemu wycinkowi tego szerokiego zagadnienia, skupiając się na burzliwej w politycznym, społecznym i gospodarczym życiu Rzeczypospolitej drugiej połowie tegoż stulecia. Panowanie trzech kolejnych władców: Jana II Kazimierza Wazy, Michała Korybuta Wiśniowieckiego oraz Jana III Sobieskiego, czyli lata 1648-1696 stanowia, moim zdaniem, dość łatwą do wyodrębnienia epokę w dziejach tak polskiej polityki monetarnej, jak i poglądów monetarnych polskiej szlachty. Otwiera ja próba reformy mennictwa podjęta w pierwszych latach panowania Jana Kazimierza, a zamyka ostatnia emisja monety koronnej za Jana Sobieskiego (wznowiono ja dopiero pod rządami Stanisława Augusta Poniatowskiego). Ramy terytorialne artykułu zostały ograniczone do jednego regionu: województwa krakowskiego. Sferę moich zainteresowań zawęziłem do opinii szlachty tego obszaru na temat przyczyn kryzysu monetarnego w Rzeczypospolitej Obojga Narodów oraz łączącego się z tą kwestią pytania o odpowiedzialność za wywołanie owej gospodarczej katastrofy.

Podstawą źródłową opracowania tytułowego zagadnienia stały się opublikowane przez Adama Przybosia akta wytworzone przez sejmiki województwa krakowskiego - zbierające się w Proszowicach - oraz obradujących osobno w Zatorze księstw oświęcimskiego i zatorskiego ${ }^{14}$. Spośród rozmaitych dokumentów składających się na akta sejmikowe największą dla omawianego tematu przydatność miały instrukcje poselskie na sejmy walne oraz - szczególnie dla okresu późniejszego uchwały sejmikowe. Materiał źródłowy, jakim są instrukcje i lauda ma kilka szczególnie dla nas cennych cech, z których najważniejszą jest umożliwienie obserwacji przemian opinii większości szlacheckiej w ujęciu chronologicznym, a więc ich ewolucję. Słabością analizowanych źródeł jest zaś ich częściowa niekompletność. Niemożliwe jest też poznanie pełnego przekroju poglądów elity społecznej, a jedynie zdania tej części klasy politycznej, która czynnie uczestniczyła w sejmikowaniu, zdobywając podczas obrad pozycję dominująca, umożliwiającą przeforsowanie konkretnych zapisów w instrukcjach poselskich. Nie musiały więc one odzwierciedlać poglądów wszystkich zgromadzonych, a w niektórych przypadkach nawet i ich większości, a jedynie aktywnej grupy korzystającej z bierności pozostałych uczestników obrad.

${ }^{14}$ Akta sejmikowe województwa krakowskiego (dalej: ASWK), t. 2-5, oprac. A. Przyboś, Wrocław 1955-1984. 


\section{Deficyt krajowego pieniądza zdawkowego}

Począwszy od 1648 r. pierwszym wymienianym przez sejmikująca w Proszowicach szlachtę czynnikiem uznanym za przyczynę zaburzeń na rynku pieniężnym było „zaniedbanie kucia pieniądza” ${ }^{15}$. Przypomnijmy, że od 1627 r. ani w Koronie, ani na Litwie, ani w miastach Prus Królewskich nie emitowano monety o nominałach niskich i średnich $^{16}$. Dało się więc już odczuć jej brak w całej Rzeczypospolitej. Zaskakuje zdawkowość treści omawianego punktu instrukcji poselskiej. Nie zwrócono uwagi przykładowo na wiążący się bezpośrednio z deficytem rodzimej monety drobnej napływ rozmaitego zdawkowego pieniądza z zagranicy, co nie umknęło przecież innym sejmikom ${ }^{17}$. Faktu tego nie powinniśmy jednak interpretować jako brak świadomości Małopolan istnienia związku przyczynowo-skutkowego między tymi dwoma zjawiskami. Wręcz przeciwnie, mając ów związek na uwadze, redaktorzy instrukcji mogli świadomie pominać zjawisko zalewu rynku pieniężnego Korony obcą moneta, widząc w tym jedynie pochodną wynikająca z owej „przyczyny pierwotnej” - braku krajowych emisji. Za tą opcja przemawia fakt nieporuszenia w żadnym innym punkcie instrukcji kwestii napływu zagranicznego pieniądza, co dawało się już wówczas we znaki w całej Rzeczypospolitej. Charakterystyczne, że sejmik nie uznał również za konieczne obarczyć kogokolwiek winą za ten stan rzeczy.

\section{Niezdecydowana polityka monetarna}

Bogatsza w treść była już kolejna instrukcja, sporządzona w $1651 \mathrm{r}^{18}$ Nie zawierała ona żądania wznowienia kucia pieniądza, ponieważ postulat ten zrealizowano już rok wcześniej. Uwagę szlachty przykuło natomiast inne bulwersujace zjawisko, będące zresztą konsekwencją wprowadzanych wówczas w życie, szeroko zakrojonych, reform polityki monetarnej Rzeczypospolitej. Chodziło mianowicie o obniżenie oficjalnego kursu monety obcej w kraju, majacego poprzedzać jej całkowite

${ }^{15}$ Instrukcja, Proszowice, 11 X 1649 r., w: ASWK, t. 2, z. 2, s. 391.

${ }^{16}$ M. Gumowski, Monety polskie, Warszawa 1924, s. 112. Do nominałów „niskich” i „średnich” zaliczamy monety do wysokości orta włącznie.

${ }^{17} \mathrm{Na}$ przykład sejmikowi ziemi halickiej: Instrukcja, Halicz, 6 X 1649 r., w: Akta grodzkie i ziemskie z czasów Rzeczypospolitej Polskiej (dalej: AGZ), t. 24: Lauda sejmikowe halickie 1575-1695, oprac. A. Prochaska, Lwów 1931, s. 79.

${ }^{18}$ Instrukcja, Proszowice, 15 grudnia 1651 r., w: ASWK, t. 2, z. 2, s. 422. 
wycofanie $^{19}$. Takie działanie komisji menniczej i podskarbiego wywołało żywy sprzeciw szlachty w różnych województwach ${ }^{20}$. Ponieważ nie dysponujemy instrukcja sejmiku proszowickiego ani zatorskiego ${ }^{21}$ z jesieni 1650 r. nie możemy stwierdzić, czy także szlachta małopolska wskazywała na negatywne skutki gospodarcze urzędowego zaniżania cen pieniądza. Omawiana instrukcja z 1651 r. dostarcza nam natomiast wiadomości o tym, że zebrani wówczas w Proszowicach redaktorzy dokumentu dostrzegali szczególnie, ich zdaniem, negatywny skutek gwałtownej zmiany polityki państwa w tej materii. Wskazano bowiem, że wielką szkodę przyniosła nie sama dewaluacja monety obcej, lecz połączenie owego działania z rychłym przywróceniem jej pierwotnego kursu, co z kolei wywołać miało zamęt na rynku. Taka ocenę stanu rzeczy możemy uznać za słuszną i dojrzała. Choć sejmik nie wskazał wprost nikogo, kto miałby być odpowiedzialny za owa destabilizację, zlecał jednak swym posłom, aby „dociekali [...] przez kogo się to stało”. Możemy domniemywać, że posłowie bynajmniej poszukiwać winnych nie musieli. Powszechnie wiadome było, kto wydał akty prawne, które do owej sytuacji doprowadziły: podskarbi wielki koronny Bogusław Leszczyński, działający w przypadku pierwszego uniwersału na podstawie ustaleń komisji menniczej sejmu 1650 r., a następnie pod presją sejmików odwołujacy te zarządzenia ${ }^{22}$.

Opisane powyżej dwie przyczyny destabilizacji systemu monetarnego Rzeczypospolitej pojawiały się na kartach instrukcji poselskich sejmiku proszowickiego incydentalnie - jednorazowo. Fakt ten był spowodowany gwałtownymi w początkach panowania Jana Kazimierza zmianami w polityce menniczej państwa. Próby reformy monetarnej

${ }^{19}$ Akt Commissyey Myniczney, odprawiony $w$ Warszawie, die XVI Maij. Anno Millesimo Sexcentesimo Quinquagesimo, w: I. Zagórski, Monety dawnej Polski jako też prowincyj $i$ miast do niej niegdy należacych z trzech ostatnich wieków, Warszawa 1845 (teksty), s. 159-163. W celu wykonania postanowień komisji menniczej podskarbi wielki koronny Bogusław Leszczyński wydał 3 VI 1650 r. uniwersał - on właśnie wywołał najżywsze protesty szlachty; R. Rybarski, dz. cyt., s. 381-382.

${ }^{20}$ Instrukcja, Halicz, 31 X 1650 r., w: AGZ, t. 24, s. 86; Instrukcja, Wisznia, 7 XI 1650 r., w: AGZ, t. 21, s. 74; R. Rybarski, dz. cyt., s. 382, przytoczył w swej pracy instrukcję sejmiku lubelskiego z 7 XI 1650 r., w której szlachta również wyrażała swe głębokie niezadowolenie z nowych zarządzeń menniczych.

${ }^{21}$ Sejmik zatorski księstw oświęcimskiego i zatorskiego, jak wynika z obserwacji, często powtarzał te same postulaty co zjazd proszowicki.

${ }^{22}$ Bogusława Leszczyńskiego odpowiedzialnym za zamieszanie na rynku monetarnym widział również Mikołaj Jemiołowski, który charakteryzując jego urzędowanie, uznał za zasadne zaznaczyć, że „[jako] pierwszy monetę polską i cudzoziemską wariować począł"; Pamiętnik dzieje Polski zawierajacy: 1648-1679, oprac. J. Dzięgielewski, Warszawa 2000, s. 70. 
opartej na idei „redukcyjnej” ${ }^{23}$ upadły na samym początku piątej dekady XVII w. ${ }^{24}$, częściowo na skutek oporu szlachty przeciwko realizacji niektórych zarządzeń podskarbińskich, w przeważającej jednak części z powodu wyniszczających konfliktów zbrojnych, wobec których okazały się zwyczajnie zbyt kosztowne.

\section{Brak kontroli nad dzierżawcami mennic oraz dzierżawienie mennic obcokrajowcom}

Znacznie trwalsze miejsce wśród przyczyn zawirowań na rynku monetarnym wymienianych w dokumentach sejmikowych zyskał sobie wśród Małopolan pogląd o niewłaściwym nadzorze nad mennicami, a konkretnie, nad ich dzierżawcami. Po raz pierwszy opinię taką wyrażono na sejmiku już w $1651 \mathrm{r} \cdot{ }^{25}$ Rok później również zaznaczono, że arenda kuźni pieniądza powinna odbywać się pod nadzorem wybranych na sejmie komisarzy, choć przyczyn takiego stanowiska nie wyjawiono ${ }^{26}$. Możemy tylko wnioskować, że szlachta podejrzewała jakieś nieprawidłowości zachodzące wokół mennic.

Opinia ta ewoluowała silnie pod wpływem bieżących wydarzeń i począwszy od 1658 r. przybrała postać szczególna. Poczęto wówczas łączyć niewłaściwe funkcjonowanie zakładów menniczych z faktem dzierżawienia ich obcokrajowcom. Pogląd ten wykształcił się na skutek okoliczności zaistniałych po oswobodzeniu Krakowa spod szwedzkiej okupacji. Wówczas to dzierżawę tamtejszej mennicy koronnej obją Tytus Liwiusz Borattini wraz z Pawłem de Bono - Włosi. W latach 1661-1667 ich miejsce zają Andrzej Tymf - Niemiec. Po Tymfie zakład

${ }^{23}$ Redukcja - reforma monetarna polegająca na obniżeniu wartości konkretnego pieniądza kruszcowego mierzonej w innym (konieczne jest istnienie stanu dwuwalutowości, w którym rynkowe ceny obu rodzajów pieniądza kształtują się niezależnie od siebie). Redukcję można było przeprowadzać na różne sposoby i mogła mieć ona różne kierunki. W pierwszej połowie XVII w. popularne było żądanie redukcji ceny talara i dukata $\mathrm{w}$ monecie zdawkowej poprzez podniesienie wewnętrznej wartości tej ostatniej. Inną metodą na przeprowadzenie redukcji było wprowadzenie państwowej taksy regulującej wzajemne ceny pieniądza. W drugiej połowie XVII stulecia pojawiły się postulaty redukcji „boratynek”, czyli obniżenia ich wartości nominalnej w stosunku do monet o kursie rynkowym lub do rynkowego zbliżonym. A. Popioł-Szymańska, dz. cyt., s. 63, nie rozróżnia dwukierunkowości postulatów redukcyjnych w XVII w.

${ }^{24}$ R. Rybarski, dz. cyt., s. 382-384.

${ }^{25}$ Instrukcja, Proszowice, 15 XII 1651 r., w: ASWK, t. 2, z. 2, s. 422.

${ }^{26}$ Instrukcja, Proszowice, 11 VI 1652 r., w: tamże, s. 439. 
odzyskał Borattini2 ${ }^{27}$. Już w kwietniu 1658 r. stanowczo wyrażała się na ten temat szlachta dyktująca uchwały sejmiku proszowickiego, do czego impulsem była umowa dzierżawna zawarta przez podskarbiego Bogusława Leszczyńskiego z Borattinim niemal trzy tygodnie wcześniej $^{28}$. W instrukcji sporządzonej na tym samym zjeździe nie stwierdzono jednak tego wprost. Zapis postulował jedynie, aby dzierżawca mennicy był ,szlachcic dobrze osiadły” 29 . W podobny sposób na obcokrajowców jako źródło nieprawidłowości wskazywano w latach 1661$-1662^{30}$. Kolejne sejmiki obradujące w 1663 , 1664 i 1665 r. nie poruszyły tego problemu w swych instrukcjach. Powrócił on natomiast, $\mathrm{w}$ najostrzejszej formie, w 1666 r., kiedy to wystapił na kartach aż trzech kolejnych dokumentów ${ }^{31}$.

Dopatrywanie się przyczyn problemów monetarnych Rzeczypospolitej w poczynaniach przedsiębiorców menniczych obcego pochodzenia nie było zjawiskiem nowym. Pod wpływem okoliczności pogląd ten powrócił jedynie do życia po kilkudziesięcioletniej przerwie, największą popularnością cieszył się w początkach XVII stulecia ${ }^{32}$. Kolejne burzliwe wydarzenia na rynku monetarnym w latach 60 ., a więc „afery” zwiąane z miedzianymi szelagami Tytusa Liwiusza Borattiniego, „złotówkami” Andrzeja i Tomasza Tymfów oraz Giovannim Baptistą Amurettim, podejrzanym o sprowadzanie do Korony fałszywej monety z Mołdawii, doprowadziły do usztywnienia poglądów szlachty, najczęściej określanych jako antycudzoziemskie. W 1667 r. arendowanie mennic przez cudzoziemców przestało być wymieniane na sejmiku proszowickim jako przyczyna zapaści i pogląd ten nie powrócił już na karty instrukcji poselskich do końca interesującego nas okresu, czyli do $1696 \mathrm{r}$.

Tak gwałtowne zniknięcie tej, zdałoby się, popularnej opinii o źródle kryzysu z dokumentów łączyć należy z zamknięciem w 1666 r. mennic „złotowych” oraz „szelężnych”33. Dzierżawcy, Borattini i Tymfowie,

${ }^{27}$ M. Gumowski, dz. cyt, s. 136.

${ }^{28}$ Uchwały, Proszowice, 11 IV 1658 r., w: ASWK, t. 2, fasc. 2, s. 615.

${ }^{29}$ Instrukcja, Proszowice, 21 VI 1658 r., w: tamże, s. 639.

${ }^{30}$ Instrukcja, Proszowice, 28 III 1661 r., w: ASWK, t. 3, s. 18; Instrukcja, Proszowice, 30 I 1662 r., tamże, s. 52 n.

${ }^{31}$ Instrukcja, Zator, 27 I 1666 r., w: tamże, s. 113; Instrukcja, Proszowice, 3 II 1666 r., w: tamże, s. 118-119; Instrukcja, Zator, 22 IX 1666 r., w: tamże, s. 152. Ostry atak na dzierżawców mennic w 1666 r. przyniósł skutek - znienawidzone mennice zamknięto.

${ }^{32}$ Z. Sadowski, dz. cyt., s. 175, 191; A. Popioł-Szymańska, dz. cyt., s. 55.

${ }^{33}$ M. Gumowski, dz. cyt., s. 134. Numizmatyka zna rzadkie egzemplarze „boratynek" datowanych na 1667 i 1668 r. Nie jest pewne, jak należy tłumaczyć ich występowanie, nawet przy założeniu, że emisję miedzianego szelaga wstrzymano dopiero na początku $1667 \mathrm{r}$. 
stanęli przed sądem, lecz pierwszy zdołał się obronić, a pozostali dwaj zbiegli z kraju. Borattini odzyskał nawet owe zyskowne dzierżawy, które utrzymał aż do swej śmierci w $1681 \mathrm{r}^{34}$ Zdołał też przekonać sejm, że Rzeczpospolita jest mu winna znaczne sumy. Fakt, że po 1666 r. nie obwiniano już na sejmiku proszowickim obcokrajowców za kryzys monetarny wobec wciąż aktywnej działalności jednego z głównych „oskarżonych” może zadziwiać. Jedyne wytłumaczenie, jakie możemy tu zaproponować, to pogodzenie się szlachty z uniewinniającymi Borattiniego wyrokami sądów. Upatrywanie źródła omawianych $\mathrm{w}$ tym miejscu postulatów jedynie $\mathrm{w}$ szowinizmie szlachty jest dużym uproszczeniem. Były one znacznie głębiej zakorzenione w szlacheckiej mentalności i wynikały także z przekonania, że szlachectwo oraz majętność sa dobrymi gwarantami uczciwości. Postulat, aby dzierżawę mennicy krakowskiej oddać jednemu spośród panów osiadłych w województwie, „sassiadowi”, miał dać szlachcie również możliwość kontroli, uzyskiwania informacji (sprawozdawczości) „z pierwszej ręki" na sejmikach oraz ewentualnego wywierania nacisków. W ten sposób być może planowano złamać faktyczny monopol podskarbiego na prowadzenie polityki monetarnej. Z perspektywy sejmików obcokrajowiec, nieczujący związku z polskim stanem szlacheckim, niezakotwiczony w Rzeczypospolitej przez majątek ziemski, a więc całkowicie uzależniony od podskarbiego i dworu, nie był osobą godna zaufania - w najlepszym wypadku stanowił jedynie narzędzie w rękach swych mocodawców.

Odpowiedzialność za niedostateczną kontrolę nad mennicami oraz dzierżawienie ich, wbrew woli szlachty, obcokrajowcom ponosić mieli podskarbiowie - do 1658 r. Bogusław Leszczyński, a po nim Jan Kazimierz Krasiński, szczególnie mocno krytykowany za zawieranie umów z Borattinim i Tymfami.

\section{Nieprawidłowości w pracy mennic - przestępstwa okołomennicze}

Szlachta województwa krakowskiego dopatrywała się przyczyn kryzysu w licznych, domniemanych nieprawidłowościach w samym funkcjonowaniu mennic. $\mathrm{O}$ ile w latach 50 . były to wciąż jeszcze problemy niewymieniane wprost $\mathrm{w}$ instrukcjach (sugerowano jedynie, że rzeczy

${ }^{34}$ Po śmierci T.L. Borattiniego dzierżawę mennicy utrzymała jego rodzina aż do $1687 \mathrm{r}$. 
nie mają się tak jak powinny) ${ }^{35}$, o tyle początek lat 60 . przyniósł w tej materii zdecydowanie większa otwartość.

Wśród owych nieprawidłowości na pierwszym miejscu wymienić należy podejrzenia o malwersację dochodów menniczych, której problem poruszały instrukcje począwszy od 1654 r. i następnie w latach 1658 , $1659,1661,1662,1665,1666$ oraz 1668, choć nie zawsze pisano o tym wprost. Środki publiczne miały być sprzeniewierzane w dwojaki sposób. $\mathrm{Z}$ jednej strony przypuszczano, że podskarbi wielki koronny Bogusław Leszczyński ${ }^{36}$ ukrywa rzeczywiste przychody z mennicy - tak sytuację oceniały najwcześniejsze wymienione instrukcje z 1654 i $1658 \mathrm{r}^{37}$ $\mathrm{Z}$ drugiej zaś strony, w późniejszych instrukcjach niedwuznacznie sugerowano, że dzierżawcy, Borattini ${ }^{38}$ i Tymf $^{39}$, nie wywiazuja się ze swoich zobowiązań - nie wypłacają skarbowi należnych sum w części lub w całości. Podejrzewano nawet zmowę pomiędzy owymi arendarzami i kolejnym podskarbim wielkim, Janem Kazimierzem Krasińskim ${ }^{40}$. Od tego ostatniego sejmiki bezskutecznie dopominały się rachunków z mennic aż do jego ucieczki z kraju w 1668 r. i rychłej śmierci (w następnym roku $)^{41}$. Zobowiązaniami Krasińskiego sejmik proszowicki obarczył wówczas jego syna i spadkobiercę, referendarza koronnego Jana Bonawenturę Krasińskiego, domagając się od niego rozliczenia przychodów menniczych z ostatniej dekady ${ }^{42}$. Rachunków żądano również od

${ }^{35}$ Instrukcja, Proszowice, 15 XII 1651 r., w: ASWK, t. 2, z. 2, s. 422; Instrukcja, Proszowice, 11 VI 1652 r., w: tamże, s. 439; Instrukcja, Proszowice, 21 VI 1658 r., w: tamże, s. 639.

${ }^{36}$ Podskarbi wielki koronny w latach 1650-1658.

${ }^{37}$ Instrukcja, Proszowice, 19 V 1654 r., w: ASWK, t. 2, z. 2, s. 504; Instrukcja, Proszowice, 21 VI 1658 r., w: tamże, s. 639.

${ }^{38}$ Instrukcja, Proszowice, 28 III 1661 r., w: ASWK, t. 3, s. 18; Instrukcja, Proszowice, 30 I 1662 r., w: tamże, s. 52 n.

${ }^{39}$ Instrukcja, Proszowice, 19 II 1665 r., w: tamże, s. 104 n.; Instrukcja, Proszowice, 3 II 1666 r., w: tamże, s. 118 n.

${ }^{40}$ Podskarbi wielki koronny w latach 1658-1668. Szlachta małopolska zarzuciła podskarbiemu korupcję wprost w 1662 r., żądajac, aby „cokolwiek od przyjęcia urzędu swego honorarium od kontraktorów et alia quaevis ratione percepit, oddał i na tę zapłatę [wojsku] obrócił”. Możemy mieć pewność, że owi „kontraktorzy” to dzierżawcy mennic, ponieważ powyższy fragment pochodzi z punktu instrukcji poświeconego sprawie A. Tymfa; zob. [Instrukcja], Proszowice, 30 I 1662 r., w: tamże, s. 52 n. Na temat działań korupcyjnych A. Tymfa pisano również w 1665 r., lecz nie wskazano, kogo konkretnie miałby on przekupywać; zob. Instrukcja, Proszowice, 19 II 1665 r., w: tamże, s. $104 \mathrm{n}$.

${ }^{41}$ Sejmik proszowicki domagał się rachunków od J.K. Krasińskiego w 1662 r.; Instrukcja, Proszowice, 30 I 1662 r., w: tamże, s. 52 n.

${ }^{42}$ Manifestacja szlachty województwa krakowskiego w Krakowie 25 X 1669 r., w: tamże, s. 290. 
współpracowników podskarbiego, jak chociażby od wojskiego krakowskiego Michała Rupniowskiego, który przez pewien czas pełnił funkcję superintendenta przy mennicy krakowskiej ${ }^{43}$. Wspomnijmy tu także, że sejmik zatorski jeszcze w $1668 \mathrm{r}$. pisał o malwersacji państwowych przychodów menniczych, ale nie wymieniał żadnych podejrzanych ${ }^{44}$.

Najistotniejszą pozycję wśród źródeł kryzysu miała zajmować samowola i nadużywanie władzy (czyli brak konsultacji z sejmem) przez instytucje sprawujace kontrolę nad polityką mennicza państwa, a więc podskarbiego wielkiego, senatorów, komisje mennicze, lwowską komisję do zapłaty wojsku oraz superintendentów. Pierwsze oznaki tego negatywnego zjawiska zaobserwowano w 1658 r., kiedy to szlachta województwa krakowskiego uznała za zasadne przypomnienie, w dwóch kolejnych instrukcjach, wielkiemu podskarbiemu koronnemu Bogusławowi Leszczyńskiemu, że „mennica [...] właśnie do dyspozycji R.P. należy z prawa" ${ }^{45}$. Kwestia samowolnego zarządzania mennicami nabrała szczególnego znaczenia w okresie urzędowania Jana Kazimierza Krasińskiego. Wzburzenie szlachty małopolskiej odbiło się szczególnie wyraźnie w manifestacji województwa przeciwko kontraktowi podskarbiego z Borattinim i Tymfem z 1663 r. ${ }^{46}$ Ordynowanie mennicy bez zgody sejmu było $\mathrm{w}$ opinii szlachty prawdziwa praprzyczyną zapaści na rynku monetarnym.

Na pogwałcenie praw Rzeczypospolitej, rozumianej tu jako sejm, do dysponowania mennicami uwagę zwracał jeszcze w 1666 r., i to dwukrotnie, sejmik księstw oświęcimskiego i zatorskiego ${ }^{47}$. Przekroczenia kompetencji miała się dopuścić, jego zdaniem, lwowska komisja do zapłaty wojsku, bezprawnie ordynująca kuźnię pieniądza. Podobną opinię w $1668 \mathrm{r}$. wyraził poseł sejmiku proszowickiego na sejm $1667 \mathrm{r}$. Jan Odrowąż Pieniążek. Składając manifestację do ksiag grodzkich bieckich, pisał on, że komisja lwowska „wszystkie fundamenty kardynalne stanu naszego jedne naruszyła, drugie obaliła" ${ }^{48}$.

\footnotetext{
${ }^{43}$ Manifestacja, Proszowice, 28 IX 1663 r., w: tamże, s. 78.

${ }^{44}$ Instrukcja dana Samuelowi Ruseckiemu, Zator, 8 X 1668 r., w: tamże, s. 227.

${ }^{45}$ Instrukcja, Proszowice, 11 IV 1658 r., w: ASWK, t. 2, z. 2, s. 615; Instrukcja, Proszowice, 21 VI 1658 r., w: tamże, s. 615.

${ }^{46}$ Manifestacja województwa krakowskiego przeciw kontraktowi podskarbiego wielkiego koronnego, Jana Kazimierza Krasińskiego, z Boratynim [sic!] i Tymfem na sejmiku w Proszowicach 28 września 1663 r., w: ASWK, t. 3, s. 78.

${ }^{47}$ Instrukcja, Zator, 27 I 1666 r., w: tamże, s. 113; Instrukcja, Zator, 22 IX 1666 r., w: tamże, s. 152.

${ }^{48}$ Manifestacja Jana Odrowąża Pieniążka, starosty oświęcimskiego, posła z sejmiku proszowskiego na sejm 1667 r., przeciw konstytucji o kontrakcie z Boratynim [sic!] o mennicę, złożona w Bieczu 29 III 1668 r., w: tamże, s. 199.
} 
Zaznaczyć należy, że owej komisji przewodniczył właśnie podskarbi wielki koronny, tak więc zarzut samowoli dotyczył jego osoby w każdym spośród analizowanych przypadków - tu jedynie częścią odpowiedzialności podzielił się z pozostałymi komisarzami.

Opinia szlachty o nadużyciach władzy przez podskarbiego musiała być dość ściśle związana z osobą Jana Kazimierza Krasińskiego - w 1666 r. oskarżenie to pojawiło się po raz ostatni na kartach instrukcji, tak proszowickich, jak i zatorskich, i nie zostało już powtórzone do $1696 \mathrm{r}$.

Innym, szczególnie zgubnym dla krajowych stosunków monetarnych zjawiskiem miała być emisja „boratynek” oraz „tymfów” ponad wyznaczone przez sejm i komisje ilości. Fakt ten miał potęgować dodatkowo negatywne skutki emisji pieniądza o dużej różnicy między wartościa wewnętrzna a nominalna. Po raz pierwszy zarzut tego typu szlachta małopolska postawiła wobec Tytusa Liwiusza Borattiniego i jego mennicy szelężnej już w 1661 r. (,boratynki” bił on od drugiej połowy 1659 r. ${ }^{49}$. Podejrzewano wówczas, że owych „miedziaków” wybito na kwotę przekraczajaca milion złotych, na która to sejm wyraził zgodę. W kolejnych instrukcjach sejmiki proszowicki i zatorski nie poruszały już tej kwestii aż do 1665 r., kiedy wyrażono opinię o nadprodukcji ,złotówek" w mennicy Andrzeja Tymfa ${ }^{50}$. Dzierżawcę dodatkowo obciążać miał fakt, że, jak to oceniła szlachta, nadwyżkową monetę „na stronę różnym osobom wybił”. Swój proceder uprawiał więc jeśli nie ze wspólnikami, to przynajmniej z wiernymi klientami, wśród których, bazując na przeanalizowanych zapisach $\mathrm{w}$ instrukcjach, $\mathrm{z}$ dużą dozą prawdopodobieństwa możemy się dopatrywać podskarbiego Jana Kazimierza Krasińskiego. W 1666 r. całą uwagę sejmików skupił na sobie ponownie Borattini. Aż cztery instrukcje: po dwie zatorskie i proszowickie, zarzucały mu wówczas przekraczanie wyznaczonych kwot w biciu szelagów litewskich ${ }^{51}$. Wskazywano nawet konkretną liczbę: $6 \mathrm{mln}$ zł, nie sprecyzowano jednak, czy chodzi o ową nadwyżkę, czy też może całą produkcję

\footnotetext{
${ }^{49}$ Instrukcja, Proszowice, 28 III 1661 r., w: tamże, s. 18.

${ }^{50}$ Instrukcja, Proszowice, 19 II 1665 r., w: tamże, s. 104 n. Na uwage zasługuje fakt, że w instrukcjach sejmików województwa krakowskiego w ogóle nie występuje postać drugiego z braci Tymfów - Tomasza. Pojawia się on raz jedynie w Diariuszu sejmiku generalnego województw małopolskich w Nowym Mieście Korczynie 18-25 II 1669 r. Wówczas to redaktorzy dokumentu żądali: „jm. pan podskarbi według submisyjej swojej aby stawił obudwu Tymphów"; Diariusz sejmiku generalnego województw małopolskich, Nowe Miasto Korczyn, 18-25 II 1669 r., w: tamże, s. 271.

${ }^{51}$ Instrukcja, Zator, 27 I 1666 r., w: tamże, s. 113; Instrukcja, Proszowice, 3 II 1666 r., w: tamże, s. 118 n.; Instrukcja, Zator, 22 IX 1666 r., w: tamże, s. 152; Instrukcja, Proszowice, 28 IX 1666 r., w: tamże, s. 159. Podejrzewano również, że szelagi litewskie są niższej ligi niż koronne; tamże.
} 
tej monety Wielkiego Księstwa Litewskiego. Nie określono też, jakiego przedziału czasowego dane owe dotyczyły. Podejrzenia szlachty w stosunku do kuźni szelężnej potęgował dodatkowo fakt bicia tej monety w wielu różnych miejscach, rozproszonych po Rzeczypospolitej, równocześnie $^{52}$. Jak już wspomniano, prawdopodobnie w 1666 r. obie mennice - „złotowa” oraz „boratynek” - zamknięto. O nadprodukcji „złego” pieniądza, jako o przyczynie zapaści, pisali jeszcze w 1669 r. (po raz ostatni) redaktorzy instrukcji zjazdu w Zatorze, domagając się za to sądu, zarówno nad Tymfem, jak i Borattinim. Zapis ten jest szczególnie godny uwagi, gdyż wskazywał również na skorumpowanie lwowskiej komisji, ułatwiające zgubną działalność dzierżawców mennic.

Jeszcze innym okołomenniczym nadużyciem odbijającym się w opinii szlachty negatywnie na stosunkach monetarnych miało być przebijanie „starej”, pełnowartościowej monety oraz czystego kruszcu na „tymfy” o sztucznym kursie. Opinię taką sejmik proszowicki wpisał do swych instrukcji dwukrotnie ${ }^{53}$. W 1665 r. zwrócono uwagę, że w proceder zaangażowane były osoby trzecie - prywatne, które przekuwając pieniądz o wewnętrznej wartości równej bądź bliskiej nominalnej na „tymfy”, zyskiwały nawet do $250 \%$ wartości kapitału zaangażowanego ${ }^{54}$. W 1667 r. redaktorzy wymienili talary i orty jako te nominały, które Andrzej Tymf najczęściej miał przerabiać w swoim zakładzie.

Podejrzenia o nieprawidłowości w pracy mennic najczęściej, w zestawieniu z innymi dostrzeganymi przyczynami problemów na rynku monetarnym, opierały się na pogłoskach. Należy zdać sobie sprawę, że szlachta była często skazana na wykorzystywanie tak wątpliwych źródeł. Stan ten w znacznej mierze wynikał z braku informacji na temat faktycznie prowadzonej polityki monetarnej, płynących ze sfer oficjalnych - przede wszystkim od podskarbiego. Choć szlachta nieustannie dopominała się przedstawienia rozliczeń, zwłaszcza od podskarbiego wielkiego koronnego Jana Kazimierza Krasińskiego, a niekiedy także od dzierżawców, jej prośbom nigdy w pełni nie zadośćuczyniono, co,

${ }^{52}$ Instrukcja, Proszowice, 28 III 1661 r., w: ASWK, t. 3, s. 18; Instrukcja, Proszowice, 3 II 1666 r., w: tamże, s. 118 n.; Instrukcja, Zator, 22 IX 1666 r., w: tamże, s. 152; Instrukcja dana Samuelowi Ruseckiemu, Zator, 8 X 1668 r., w: tamże, s. 227. „Boratynki” bito w zakładach na Zamku Ujazdowskim pod Warszawa, w Krakowie, Brześciu Litewskim, Wilnie, Oliwie, Kownie i Malborku. Mennica malborska zwróciła na siebie szczególną uwagę szlachty, gdyż została założona bezprawnie; Instrukcja, Proszowice, 3 II 1666 r., w: tamże, s. 118 n.

${ }^{53}$ Instrukcja, Proszowice, 19 II 1665 r., w: tamże, s. 104 n.; Instrukcja, Proszowice, 7 II 1667 r., w: tamże, s. 170.

${ }^{54}$ Nie wliczając kosztów miedzi potrzebnej do stopu oraz zakładając sytuację idealna, że na rynku „złotówki” byłyby w obrocie w ich wartości nominalnej. 
w sposób naturalny, skłaniało do przekonania o słuszności oskarżeń. Niedoinformowanie szlachty wynikało więc z głębokich zaburzeń funkcjonowania systemu państwowego, przejawiających się m.in. faktycznym brakiem kontroli sejmu nad działalnością podskarbiego.

\section{Emisja „boratynek” i „tymfów”}

Z wymienionymi wyżej nieprawidłowościami wiązała się ściśle podstawowa, tak w opinii szlachty, jak i w rzeczywistości, przyczyna dystorsji na rynku monetarnym lat 60 . XVII w. oraz kolejnych dekad, jaka była emisja szelagów miedzianych nazywanych popularnie „boratynkami” oraz srebrnych, trzydziestogroszowych złotówek zwanych „tymfami”"55. Być może redaktorzy instrukcji proszowickiego sejmiku dawali się ponieść emocjom, gdy pisali, że „żadna klęska, które się zdały sprzysiężone na dotąd udręczoną Ojczyznę naszę, nie osłabiły tak R.P., jako ta powszechna zguba, zarażona mennica"56, nie sposób jednak nie zgodzić się z tak postawioną diagnozą przyczyn kryzysu krajowych stosunków monetarnych. Oba krytykowane gatunki monet charakteryzowała znaczna różnica między ich wartością nominalną a wewnętrzna, czyli rzeczywistą ceną kruszcu w nich zawartego, co z kolei spowodowało wypieranie przez nie $\mathrm{z}$ rynku w pierwszej kolejności pełnowartościowego pieniądza krajowego, a następnie obcego ${ }^{57}$. To w emisjach „boratynek” i „tymfów” małopolska szlachta widziała główną przyczynę kryzysu monetarnego Rzeczypospolitej. Po raz pierwszy stwierdzenie takie padło już w instrukcji na sejm $1661 \mathrm{r}$. danej na sejmiku proszowickim $^{58}$. Z przyczyn obiektywnych dotyczyło ono wówczas jedynie

${ }^{55}$ Miedziane szelagi, „boratynki”, emitowano w latach 1659-1666 (1667?), natomiast złotówki, „tymfy”, w latach 1663-1666.

${ }^{56}$ Instrukcja, Proszowice, 23 VII 1668 r., w: ASWK, t. 3, s. 220.

${ }^{57}$ Adam Szelagowski cała wina za wywołanie kryzysu na rynku monetarnym Rzeczypospolitej obarczył „tymfy”, a nie „boratynki”; tenże, Upadek waluty w Polsce za Jana Kazimierza, KH, t. 15, 1901, z. 1-4, s. 18-44. Było to twierdzenie błędne: najbardziej zgubne konsekwencje miały wszak przymusowe kursy obu nominałów, przy czym kurs „złotówek” był znacznie korzystniejszy niż miedzianych szelagów (wartość rzeczywista „tymfa” wynosiła ok. 40\% jego wartości nominalnej, podczas gdy w przypadku „boratynki” było to zaledwie 15\%). Dodajmy jeszcze, że „boratynek” wyemitowano, zgodnie z rozmaitymi umowami zawieranymi z Borattinim, na zawrotną sumę 18 mln zł; S. Janušonis, Nieznane rachunki z lat 1663-1667 dotyczqce bicia miedzianych szelagów w mennicach W. Ks. Litewskiego, „Wiadomości Numizmatyczne” 19, 1975, z. 2, s. 105-114.

${ }^{58}$ Instrukcja, Proszowice, 28 III 1661 r., w: ASWK, t. 3, s. 18. 
szelagów Borattiniego. Kwestię szkodliwości emisji obu rodzajów monet poruszono dwa lata później w Manifestacji województwa krakowskiego przeciw kontraktowi podskarbiego wielkiego koronnego, Jana Kazimierza Krasińskiego, z Borattinim i Tymfem na sejmiku w Proszowicach z 1663 r. ${ }^{59}$ Poza instrukcja z 1665 r. ${ }^{60}$, poruszająca problem mennicy „złotowej”, wszystkie kolejne dokumenty oceniały działalność kuźni pieniądza jako szkodliwa, nie określając, o która - Borattiniego czy Tymfa - konkretnie chodzi ${ }^{61}$.

Opinia o emisji „boratynek” i „tymfów” oraz o nieprawidłowościach jej towarzyszących jako o przyczynach kryzysu monetarnego nie znalazła odbicia w dokumentacji sejmikowej po 1669 r. Nie przestała jednak przecież funkcjonować wśród szlachty wraz z zamknięciem mennicy szelężnej i złotowej (1666 r. $)^{62}$. Ten stan rzeczy związany jest ze specyfiką wykorzystywanego źródła. Celem instrukcji było wskazanie bieżącego problemu oraz ewentualne zaproponowanie metody zaradczej (lub zaznaczenie, na jaką metodę nie można się zgodzić itp.). Kiedy zlikwidowano więc problem złej mennicy, przestano go roztrzasać na zjazdach szlacheckich. Funkcjonował on jeszcze wprawdzie przez pewien czas w kontekście spraw sądowych toczących się przeciwko dzierżawcom, lecz wkrótce został całkowicie zastapiony nowym zagadnieniem - nieprzerwanym obiegiem „boratynek” i „tymfów” na polskim rynku.

Co ciekawe, szlachta krakowska niechętnie wskazywała, kto jest odpowiedzialnym za emisję „złej” monety. Z treści dokumentów takich jak manifestacja województwa złożona przeciwko kontraktowi podskarbiego wielkiego koronnego z Borattinim i Tymfem ${ }^{63}$ domyślać się możemy, że - podobnie jak na innych sejmikach ${ }^{64}$ - większą część winy składano na podskarbiego wielkiego koronnego Jana Kazimierza

${ }^{59}$ Manifestacja, Proszowice, 28 IX 1663 r., w: tamże, s. 78.

${ }^{60}$ Instrukcja, Proszowice, 19 II 1665 r., w: tamże, s. 104 n.

${ }^{61}$ Instrukcja, Zator, 27 I 1666 r., w: tamże, s. 113; Instrukcja, Proszowice, 3 II 1666 r., w: tamże, s. 118 n.; Instrukcja, Zator, 22 IX 1666 r., w: tamże, s. 152; Instrukcja, Proszowice, 14 XII 1667 r., w: tamże, s. 192; Instrukcja, Proszowice, 23 VII 1668 r., w: tamże, s. 220; Instrukcja, Proszowice, 15 X 1668 r., w: tamże, s. 237; Instrukcja, Zator, 11 VIII 1669 r., w: tamże, s. 286.

62 Zob. przyp. 31.

${ }^{63}$ Manifestacja, Proszowice, 28 IX 1663 r., w: ASWK, t. 3, s. 78.

${ }^{64}$ Instrukcja, Halicz, 4 II 1662 r., w: AGZ, t. 24, s. 190; Instrukcja, Halicz, 20 IX 1666 r., w: tamże, s. 229; Instrukcja, Halicz, 3 III 1667 r., w: tamże, s. 243; Articuli conventus particularis Radziejoviensis, 17 II 1666 r., w: Dzieje Ziemi Kujawskiej oraz akta historyczne do nich stużace, t. 2: Lauda i instrukcye 1572-1674, oprac. A. Pawinski, Warszawa 1888, s. 155; zob. też Articuli seu puncta ex unanimi consensu conventus particularis Radziejoviensis pro comitiis generalibus Varsaviensibus servientes ordinais, 19 XII 1667 r., w: tamże, s. 194. 
Krasińskiego, jako zwierzchnika polityki monetarnej państwa oraz przewodniczącego lwowskiej komisji zapłaty wojsku, a także na pozostałych członków tego kolegium i na superintendenta mennicy Michała Rupniowskiego. Również w 1668 r. zjazd proszowicki obarczył wina całą komisję, wymieniając obok niej również senatorów ${ }^{65}$.

\section{Obieg „boratynek” i „tymfów” po zamknięciu mennic}

Po zaprzestaniu produkcji „złej” monety, jak wówczas określano miedziane szelagi i niepełnowartościowe „złotówki”, jako podstawowa przyczynę kryzysu monetarnego nękającego Koronę i Litwę szlachta małopolska wymieniała dalszy obieg tego pieniądza. Przymusowy kurs „boratynki”, choć z czasem obniżany, doprowadził do poważnego uszczuplenia ilości pieniądza złotego i srebrnego na rynku (czy to przez tezauryzację, czy też wyprowadzenie kruszcu za granicę). W końcu nawet i „tymfy” zaczęto traktować jako pieniądz „lepszy”.

Na problem ciagłego kursowania niepełnowartościowego pieniądza sejmiki województwa krakowskiego zaczęły zwracać uwagę bezpośrednio po zamknięciu mennic w $1666 r{ }^{66}$ Za wyraziciela powszechnej, jak się zdaje, w tej materii opinii, uznać możemy Jana Odrowąża Pieniażka, starostę oświęcimskiego i posła województwa krakowskiego na sejm w 1667 r.: ,[Monetę] jako złą uznawam zarazę R.P., która wszystkie splendory tej Ojczyzny pożarła, która prywatnych tylko bogaci, a powszechnie wprowadziła nie zbyte podobno w długie lata ubóstwo, która niesie znaki domowym zamieszaniom, która ceny ogromnie wyniosła, która handle wyplenia, z tej Korony [...], która jako mróz powarzyła wszystkie ozdoby tej Ojczyzny i ze złotej, srebrnej R.P. miedzianą uczyniła"67.

${ }^{65}$ Instrukcja, Proszowice, 15 X 1668 r., w: ASWK, t. 3, s. 237. Do grona senatorów-ministrów zaliczał się, rzecz jasna, i podskarbi wielki koronny, lecz zastosowany zwrot ex senatus consillis jednoznacznie wskazuje, że zamieszana była większa grupa dostojników.

${ }^{66}$ Instrukcja, Proszowice, 14 XII 1667 r., w: ASWK, t. 3, s. 192; Manifestacja Jana Odrowąża Pieniążka, starosty oświęcimskiego, posła z sejmiku proszowskiego na sejm 1667 r., przeciw konstytucji o kontrakcie z Boratynim o mennicę, Biecz, 29 III 1668 r., w: tamże, s. 199; Instrukcja, Proszowice, 10 XII 1676 r., w: ASWK, t. 4, s. 59 n.; Instrukcja, Proszowice, 16 XII 1687 r., w: ASWK, t. 5, s. 63. Pośrednio na obieg „boratynek” i „tymfów” jako na źródło zaburzeń gospodarczych wskazuje również: Instrukcja, Zator, 11 VIII 1669 r., w: ASWK, t. 3, s. 285 n.

${ }^{67}$ Manifestacja Jana Odrowąża Pieniążka, starosty oświęcimskiego, posła z sejmiku proszowskiego na sejm 1667 r., przeciw konstytucji o kontrakcie z Boratynim [sic!] o mennicę, Biecz, 29 III 1668 r., w: ASWK, t. 3, s. 199. 
Pogląd ten przez lat kilka współistniał w instrukcjach z wcześniejszym, wskazującym na emisje „boratynek” i „tymfów” jako na podstawowe źródło zaburzeń. Z czasem również i zagadnienie obiegu „złej” monety poruszano coraz rzadziej. Był to zapewne efekt marazmu, który stopniowo ogarniał sejmikujacych po wieloletniej i bezskutecznej walce z monetarna „zarazą. Ostatni zapis w instrukcji sejmiku województwa krakowskiego, jaki możemy tu przytoczyć, pochodzi z 1687 r., a jego treść, pomimo upływu dwóch dekad od zaprzestania emisji, dowodzi, jak wciąż wielką bolączką był dla szlachty obieg „złego” pieniądza. Stwierdzono w nim: „nic tak klęska żadna a nawet gwałt wrogich poczynań może R.P., jako zła moneta i waryjacyja jej osłabiła w tym czasie"68.

Szlachecka krytyka nieprzerwanego funkcjonowania na rynku „złego” pieniądza jest zrozumiała. Równoczesny obieg monet niepełnowartościowych, o wartości nominalnej sankcjonowanej urzędowo oraz monet o wartości rynkowej, jest sytuacja patologiczną i, zgodnie z poczynionymi przez Jana Odrowąża Pieniążka obserwacjami, prowadzi do wielu zaburzeń gospodarczych.

Charakterystyczne, że za obieg „boratynek” i „tymfów” nikogo nie obarczano osobistą odpowiedzialnościa. Szlachta zdawała sobie zapewne sprawę, że nie była to kwestia wytypowania jednej osoby lub jakiejś waskiej grupy. Winny był, z jednej strony, system polityczny Rzeczypospolitej i jego postępujący paraliż, z drugiej zaś wyniszczenie i zubożenie państwa. Razem oba te czynniki utrwalały kryzys monetarny, który z kolei poważnie utrudniał podźwignięcie się kraju z ruiny.

\section{Zbyt niska lub zbyt wysoka stopa emitowanych monet}

Szlachta małopolska dostrzegała również negatywne dla gospodarki skutki emitowania pieniądza o zbyt wysokiej wartości wewnętrznej (niskiej stopie menniczej). Na fakt ten, w kontekście reformy monetarnej z 1650 r., zwrócił uwagę zjazdu proszowickiego książę wojewoda Władysław Dominik Ostrogski-Zasławski w swym wotum na sejmiku $1654 \mathrm{r} .{ }^{69}$ Być może część szlachty przekonał on wówczas do swych racji,

${ }^{68}$ Instrukcja, Proszowice, 16 XII 1687 r., w: ASWK, t. 5, s. 63.

${ }^{69}$ Votum Władysława Ostrogskiego-Zasławskiego, wojewody krakowskiego, na sejmiku przedsejmowym województwa krakowskiego w Proszowicach, 19 V 1654 r., w: ASWK, t. 2, z. 2, s. 500. Votum księcia Ostrogskiego-Zasławskiego było, wbrew twierdzeniu A. Popioł-Szymańskiej, dz. cyt., s. 65, niezwykle krytyczne wobec reformy monetarnej z 1650 r. i stanowiska komisji menniczej, która ją postanowiła. Na poparcie tej tezy przytoczmy tu fragment owego dokumentu: „Spodziewaliśmy się, że 
lecz w instrukcji poselskiej sporządzonej na tym zjeździe domagano się, aby emitowano pieniądz tak dobry jak za panowania Zygmunta III, czyli, w większości wypadków, wewnętrznie lepszy od monet bitych według ordynacji menniczej z $1650 \mathrm{r}^{70}$

mienica miała wielki pożytek R. P. przynieść, aż i pożytku nie masz i mienica zginęła. A to dlatego, że pieniądze lepsze nisz obce poczęto robić, na czym żadnego zysku nie było, owszem wszytkie te dobre pieniądze powykupywano [...]". Nieprawdziwe jest też stwierdzenie badaczki jakoby komisarze w 1650 r. zamierzali „dokonać rewaluacji własnego [polskiego] pieniądza” (tamże, s. 65). Jeszcze na tej samej stronie autorka zaprzeczyła samej sobie, pisząc, że kierowano się „rachubą na nieopłacalność spekulacji po obniżeniu wartości monety krajowej”. Ostatnie zdanie zaczerpnięte zostało z samego źródła - odnajdziemy je w Akcie Commissyey Myniczney, odprawionym w Warszawie, die XVI Maij. Anno Millesimo Sexcentesimo Quinquagesimo, w: I. Zagórski, dz. cyt., s. 160. Powtórzenie go należy jednak ocenić jako niefortunne, gdyż poza nieznaczna w stosunku do potrzeb dewaluacją monety zdawkowej, decyzją komisji podniesiono wartość wewnętrzną orta i talara (punktem odniesienia powinna być dla nas ordynacja mennicza z 1623 r.: Oblata Ordinationis Cudende Monetae. Dat. 13 Marca 1623. Obl. 17 Marca t. r., w: I. Zagórski, dz. cyt., s. 140-142). Dane liczbowe zawarte w obu ordynacjach można porównać, korzystając z tabel sporządzonych przez M. Gumowskiego (tenże, Podręcznik numizmatyki polskiej, Kraków 1914, s. 290). Komisja mennicza z 1650 r. miała za zadanie uregulować wzajemne ceny różnych gatunków srebrnej monety krajowej, tak aby faktyczna wartość wewnętrzna była jak najbliższa nominalnej i przedstawiała się następująco: 18 groszy $=9$ dwojaków $=6$ trojaków $=3$ szóstaki $=1$ ort. Planowano też uregulować relację monety obcej $\mathrm{w}$ stosunku do krajowej. Cele te zamierzano osiagnać na drodze wielokierunkowej „redukcji”, czyli: 1) obniżenia wartości nominalnej pieniądza zagranicznego do jego wartości wewnętrznej (redukcja nominalna) i w perspektywie jego wywołanie, 2) obniżenie wartości wewnętrznej drobnego pieniądza krajowego (od szelaga do szóstaka; redukcja wewnętrzna), 3) podniesienie wartości wewnętrznej orta i talara (szczególnie tego pierwszego; redukcja wewnętrzna odwrócona - obniżenie ceny monety drobnej oraz równoczesne zniżenie nominalnej ceny dukata wyrażonej $\mathrm{w}$ monecie grubej srebrnej). Wielokierunkowości redukcji i ogromnej złożoności znaczenia występujacego w źródłach pojęcia „redukcja” A. Popioł-Szymańska, jak i inni badacze, zdają się w ogóle nie zauważać. Szczytna idea przyświecająca działalności komisji menniczej z 1650 r. w praktyce okazała się dla gospodarki szkodliwa. Stało się tak, ponieważ działania państwa w tej materii były bardzo niekonsekwentne: zrezygnowano ze zmian cen pieniądza obcego po protestach szlachty zagrożonej utratą części kapitału, kontynuowano natomiast emisję polepszonej monety. Doprowadziło to, jak słusznie zauważył wojewoda krakowski, do zniknięcia owej lepszej monety z rynku. Czy reforma miała w ogóle szansę na powodzenie pozostaje kwestią otwarta. Zwrócić należy jednak uwagę, że wobec skromności narzędzi administracyjnych państwa oraz braku organów przymusu, a także w związku z pogarszająca się koniunktura w Europie i tocząca się wojną domową (powstanie Chmielnickiego) szanse te uznać należy za znikome.

${ }^{70}$ Instrukcja, Proszowice, 19 V 1654 r., w: ASWK, t. 2, z. 2, s. 504. Pomijajac orty i talary, które zgodnie z ordynacją 1623 r. byłyby wewnętrznie słabsze od nowych emisji. 
W 1659 r. wśród panów krakowskich redagujących instrukcję poselską przewagę zdobył pogląd o szkodliwości dla krajowych stosunków monetarnych emisji pieniądza o zbyt niskiej wartości wewnętrznej ${ }^{71}$. Ponieważ szlachta nie wskazała wówczas, jaka moneta powinna być bita, nie możemy stwierdzić, o ile wartość ta była zaniżona względem oczekiwań obradujących. Podobne opinie nie występowały w instrukcjach poselskich z lat kolejnych aż do lipca 1668 r., kiedy to zapisano wniosek, ,żeby orty i szóstaki tak złe nie były, ale według należytej bite były ligi" ${ }^{2}$. Znów więc nie wiemy, co mamy rozumieć pod postulatem owej „należytej” ligi pieniądza (czy chodzi o przestrzeganie obowiązującej ordynacji menniczej?) i wobec lakonicznej relacji źródłowej trudno rzetelnie ocenić słuszność zgłaszanego postulatu.

\section{Wchodzenie na rynek monetarny Rzeczypospolitej pieniądza obcego}

Szlachta małopolska widziała również źródło niemałych zaburzeń na rynku monetarnym we wprowadzanych do Rzeczypospolitej monetach obcych. Uwagę sejmiku proszowickiego w 1661 i 1666 r. przykuły „szelagi ryskie”, czyli drobny pieniądz o niskiej zawartości srebra bity, na podobieństwo polskich odpowiedników, w Rydze przez Szwedów ${ }^{73}$. Niejako przy okazji w obu omawianych dokumentach wyrażono również sprzeciw wobec napływu innej, niespecyfikowanej monety zagranicznej do Korony.

\section{Falszerstwa monetarne}

Szczególne miejsce wśród dostrzeganych przez szlachtę sejmiku proszowickiego przyczyn monetarnego załamania zajmowały fałszerstwa. Po raz pierwszy na problem ten zwrócono uwagę w $1666 \mathrm{r}^{74}$ Wskazano wówczas, że przez nieuwage podskarbiego Jana Kazimierza Krasińskiego do Rzeczypospolitej wprowadzone zostały fałszywe szelagi

${ }^{71}$ Instrukcja, Proszowice, 18 II 1659 r., w: tamże, s. 666 n.

${ }^{72}$ Instrukcja, Proszowice, 23 VII 1668 r., w: ASWK, t. 3, s. 220.

${ }^{73}$ Instrukcja, Proszowice, 28 III 1661 r., w: tamże, s. 18; Instrukcja, Proszowice, 3 II 1666 r., w: tamże, s. 118-119. Szelagi te miały zawierać jedynie 11\% czystego srebra; zob. E. Mrowiński, Monety Rygi, Warszawa 1986, s. 63 n.

${ }^{74}$ Instrukcja, Proszowice, 3 II 1666 r., w: ASWK, t. 3, s. 119. 
suczawskie, w źródle zwane „wołoskimi”75. O ten przestępczy czyn oskarżono Giovaniego Amurettiego. Pojawienie się jednak w tym kontekście także nazwiska podskarbiego, którego chciano zresztą zobowiązać do wynagrodzenia wszystkich szkód wywołanych „złą, obcą monetą może skłaniać do przypuszczenia, że w postępowaniu ministra widziano coś więcej niż tylko zwykła „nieuwagę”. Po raz kolejny do kwestii szelagów „wołoskich” sejmik proszowicki powrócił jeszcze w instrukcji z jesieni $1668 \mathrm{r}^{76}$ Nie wskazano już wówczas żadnych osób odpowiedzialnych za ich rozpowszechnianie, ograniczono się jedynie do stwierdzenia, że pieniądz ten wwieziony został przez pograniczne komory celne.

Zjawiskiem o odmiennym charakterze, zaobserwowanym przez szlachte małopolska, był wzrost rodzimej produkcji fałszerskiej. $\mathrm{Na}$ problem ten zwrócono uwagę w 1668 r., pisząc, ,że się znajdują tacy, którzy zdeptawszy dość surowe prawa, śmią się ważyć fałszywą zarażać moneta" ${ }^{\prime 77}$. Nie wskazano wówczas, jaka moneta miałaby padać ofiara oszustów. Na kartach instrukcji znajdujemy natomiast wymienione jedno nazwisko osoby o proceder ten podejrzanej - miał być to bliżej nam nieznany rotmistrz Czeczel.

Kolejne zapisy w dokumentach sejmików województwa krakowskiego poświęcone fałszerstwom monetarnym pochodzą dopiero z końca lat 70. i 80. XVII w. W instrukcjach na sejmy 1679 i 1682 r. redaktorzy wskazywali na rozpowszechnienie się tego typu przestępczości ${ }^{78}$. Ograniczono się jednak do postulatu ścigania i karania, nie wskazując żadnego konkretnego winowajcy. Nie określono również, jaki gatunek pieniądza miałby być tu podrabiany, choć z dużą dozą prawdopodobień-

${ }^{75}$ Lata 60. XVII w. przyniosły również największą w całym stuleciu aferę fałszerska. W 1662 r. w Suczawie na Mołdawii tamtejszy hospodar Istrate Dabija otworzył mennicę, której głównym zadaniem było bicie fałszywych szelagów szwedzkich, polskich, litewskich i pruskich na rynek Rzeczypospolitej. Mennictwo suczawskie, z racji na jego intensywność, miało fatalny wpływ na sytuację monetarna Korony i Litwy. Ponieważ owe fałszerstwa zalały rynek pieniężny Rzeczypospolitej, niekiedy określa się je mianem „trzeciego potopu monetarnego”. O współpracę przy tworzeniu mennicy Dabiji oskarża się niekiedy Tytusa Liwiusza Borattiniego, który w 1662 r. opuścił Koronę. Nie sposób jednak stwierdzić słuszności lub nieprawdziwości owych sugestii; zob. A. Mikołajczyk, Fałszerska mennica w Suczawie, „Wiadomości Numizmatyczne” 24, 1980, z. 4, s. 197-224; T. Kałkowski, Tysiqc lat monety polskiej, Kraków 1981, s. 276-277; Wtosi w Polsce, t. 1: Tytus Liwjusz Boratyni, dworzanin króla Jana Kazimierza, mincerz i uczony, Kraków 1922.

${ }^{76}$ Instrukcja, Proszowice, 3 II 1666 r., w: ASWK, t. 3, s. 118 n.; Instrukcja, Proszowice, 15 X 1668 r., w: tamże, s. 237.

${ }^{77}$ Instrukcja, Proszowice, 23 VII 1668 r., w: tamże, s. 220.

${ }^{78}$ Uchwały sejmiku relacyjnego, Proszowice, 5 VI 1679 r., w: ASWK, t. 4, s. 107; Instrukcja, Proszowice, 16 XII 1682 r., w: ASWK, t. 5, s. 23. 
stwa przypuszczać możemy, że chodziło głównie, jeśli nie wyłącznie, o „boratynki”.

Miedziane szelagi z nazwy wymieniono dopiero w dokumencie z 1685 r., gdzie również, jedyny raz w znanej dokumentacji sejmiku proszowickiego, nazwano je „klepaczami” oraz stwierdzono, że sa podrabiane również poza granicami Rzeczypospolitej ${ }^{79}$. $\mathrm{Na}$ „boratynki” jako na przedmiot fałszerstwa wskazano ponownie w 1688 r. ${ }^{80}$ Szczególnie interesujacca informacje odnajdujemy w liście wojewody sieradzkiego Jana Odrowąża Pieniążka na sejmik proszowicki 1696 r. ${ }^{81}$ Choć w treści ponownie nie wymieniono, o jaki rodzaj monety idzie, stwierdzono jednak rzecz znamienna - fałszerskim rzemiosłem trudnić się mieli Żydzi. $\mathrm{Z}$ perspektywy czasu nie sposób jednoznacznie potwierdzić lub zaprzeczyć takiemu zjawisku. Z późniejszych o stulecie źródeł dowiadujemy się jednak, że rzeczywiście przedstawiciele tej mniejszości mogli mieć istotny udział $\mathrm{w}$ omawianym procederze przestępczym ${ }^{82}$.

Zaskakujące może się wydawać, że wśród dostrzeganych przez szlachtę województwa krakowskiego przyczyn kryzysu monetarnego nie wymieniono spekulacji, drożyzny monety talarowej i dukatów oraz wywozu dobrego pieniądza z kraju. Wymienione kwestie postanowiłem tu pominaćc, gdyż, jak mniemam, wbrew opinii wyrażonej w literaturze przedmiotu ${ }^{83}$ szlachta uważała je bezsprzecznie za skutek zapaści, co potwierdzają relacje źródłowe. W 1667 r. redaktorzy instrukcji sejmiku proszowickiego stwierdzili, że „ceny [...] za złą monetę ogromnie wzrastają i kupcy z Żydami pieniędzmi handlując, wielkie zarobki mają" ${ }^{\$ 4}$. Żadnej wątpliwości nie pozostawia nam Jan Odrowąż

${ }^{79}$ Uchwały powtórnego sejmiku relacyjnego, Proszowice, 16 VIII 1685 r., w: ASWK, t. 5 , s. 43 .

${ }^{80}$ Instrukcja, Proszowice, 5 XI 1688 r., w: ASWK, t. 4, s. 79.

${ }^{81}$ List Jana Odrowąża Pieniążka, wojewody sieradzkiego, na sejmik województwa krakowskiego w Proszowicach, Kazimierz, 24 VII 1696 r., w: ASWK, t. 5, s. 174. Postanowiłem omówić tu tę interesującą opinię, choć spisano ją już miesiąc po śmierci Jana III Sobieskiego.

${ }^{82}$ G. Skapski, Fatszerstwa monetarne $w$ czasach Stanisław Augusta Poniatowskiego, w: Fałszerstwa i naśladownictwa monet. XI ogólnopolska sesja numizmatyczna w Nowej Soli, Poznań 1998.

${ }^{83}$ A. Popioł-Szymańska, dz. cyt.

${ }^{84}$ Instrukcja, Proszowice, 7 II 1667 r., w: ASWK, t. 3, s. 170; zob. też Instrukcja, Proszowice, 14 XII 1667 r., w: tamże, s. 192; Uchwała, Proszowice, 16 IV 1668 r., w: tamże, s. 205; Uchwała, Proszowice, 8 I 1669 r., w: tamże, s. 247; Instrukcja, Proszowice, 31 XII 1675 r., w: ASWK, t. 4, s. 27; Instrukcja, Proszowice, 29 XI 1678 r., w: tamże, s. 94; Uchwała, Proszowice, 6 XI 1686 r., w: ASWK, t. 5, s. 53; Uchwała, Proszowice, 16 XII 1687 r., w: tamże, s. 66; Instrukcja, Proszowice, 19 XI 1692 r., tamże, s. 125 . 
Pieniążek w swej manifestacji z 1668 r., której dość obszerny fragment przytoczono powyżej ${ }^{85}$.

Znamienne jest także, że w aktach sejmikowych oskarżeń o wywołanie kryzysu na rynku monetarnym nigdy nie stawiano królowi, chociaż nie ulega wątpliwości, że to on patronował stronnictwu dworskiemu, do którego zaliczali się, i którego plany polityczne realizowali, m.in. Bogusław Leszczyński i Jan Kazimierz Krasiński, a także Tytus Liwiusz Borattini. Jest to, jak się zdaje, kolejny przejaw ówczesnej szlacheckiej mentalności - monarcha znajdował się poza wszelka krytyką dokumentów sejmikowych, choć negatywne opinie o Janie Kazimierzu były bardzo rozpowszechnione, a momentem ich weryfikacji stał się rokosz Lubomirskiego.

\section{Podsumowanie}

Jak łatwo zaobserwować, poglądy szlachty znajdujące swoje odbicie w instrukcjach i uchwałach redagowanych na sejmikach województwa krakowskiego w Proszowicach oraz księstw oświęcimskiego i zatorskiego w Zatorze w omawianym przedziale czasowym (1648-1696) ulegały silnym przemianom. Mamy podstawy do wyodrębnienia $\mathrm{w}$ tym procesie ewolucyjnym trzech wyraźnych okresów, łączących się ściśle $\mathrm{z}$ bieżącymi wydarzeniami w gospodarce i szeroko pojętej polityce Rzeczypospolitej. Pierwszy z nich obejmował lata 1648-1655, gdy - po postulatach wznowienia emisji zdawkowego pieniądza - obserwujemy zmiany opinii szlacheckiej na tle reformy monetarnej 1650 r. Kolejny okres przypadał na lata 1655-1668. W obliczu zniszczeń wojennych doszło wówczas do inflacyjnego bicia drobnego pieniądza. Kulminacja była tu emisja „boratynek” począwszy od 1659 r. oraz „tymfów” od 1663 r. Zmierzch następował stopniowo, począwszy od zamknięcia mennic w latach 1666-1668, kiedy z kraju zbiegł podskarbi wielki koronny Jan Kazimierz Krasiński. Ostatni okres - 1669-1696 - przypadał na stagnację $\mathrm{w}$ mennictwie krajowym, przerwaną na krótko przez emisje Jana III Sobieskiego w latach 1677-1686, gdy większość uwagi szlacheckiej przyciagały fałszerstwa oraz walka ze skutkami kryzysu i kiedy z rzadka już jedynie wskazywano na odległe w czasie rzeczywiste przyczyny zapaści.

${ }^{85}$ Manifestacja Jana Odrowąża Pieniążka, starosty oświęcimskiego, posła z sejmiku proszowskiego na sejm 1667 r., przeciw konstytucji o kontrakcie z Boratynim [sic!] o mennicę, Biecz, 29 III 1668 r., w: ASWK, t. 3, s. 199. 
Z akt sejmikowych dowiadujemy się, że za praprzyczynę kryzysu monetarnego szlachta uważała nadużywanie władzy przez podskarbiego wielkiego, komisje i senatorów, którzy bezprawnie (bez zgody sejmu) ordynowali mennice i doprowadzili do emisji „boratynek” i „tymfów”.

Uwagę zwraca częsta zdawkowość punktów poświęconych monecie $\mathrm{w}$ instrukcjach poselskich, której jednak nie należy interpretować jako przejawu indolencji szlachty. Dokumenty te stanowiły uogólnioną wykładnię jej poglądów na kwestie, które miały być poruszone na sejmie, przedstawiona $\mathrm{w}$ formie szkieletu programowego, będącego punktem wyjścia do dyskusji i zawierającego warunki wstępne i najważniejsze postulaty. Z tej przyczyny nie poświęcano wiele uwagi umotywowaniu wniosków, nie rozwodzono się też nad tym, co poprzez ich realizację zamierzano osiagnąć. $Z$ pewnością nie można jednak zgodzić się z opinia, że były one „puste”" ${ }^{86}$, przeciwnie, uznać je należy raczej za zwięzłe i treściwe.

Opinie współczesnej historiografii o poglądach monetarnych społeczeństwa polskiego, w tym szlachty, w minionych epokach zdają się wymagać poważnej rewizji. Ciążą na nich sądy wyartykułowane przez badaczy jeszcze $\mathrm{w}$ początkach XX stulecia oraz politycznie zaangażowane tezy będące $\mathrm{z}$ kolei pokłosiem okresu komunistycznego. Wciąż bez krytycyzmu powtarzane i odświeżane przez bliższą nam chronologicznie literaturę uproszczenia utwierdziły w niektórych środowiskach badawczych krzywdzący stereotyp szlachcica reprezentującego zawsze nieaktualne, w zestawieniu z mieszczaństwem oraz myślicielami epoki, wręcz prymitywne poglądy w dziedzinie gospodarczej. Tymczasem rozmaitość opinii szlacheckich obecnych na kartach akt sejmikowych skłania do ponownego podjęcia badań w zakresie dziejów kształtowania się myśli ekonomicznej klasy politycznej Rzeczypospolitej, szczególnie w szerszym kontekście kryzysów gospodarczych, takich jak ów z drugiej połowy XVII w.

\section{Bibliografia}

Bogucka M., Kryzys monetarny XVII w. Konsekwencje spoteczne i psychologiczne w Polsce, „Roczniki Dziejów Społecznych i Gospodarczych” 37, 1976, s. $87-102$.

Czarkowski J., Zarys dziejów myśli ekonomicznej w Polsce, Kraków 1948.

Dziewanowski-Stefańczyk B., Polityka monetarna za panowania Jana Kazimierza. Dyskurs sejmowy w latach 1658-1668, mps pracy doktorskiej

${ }^{86}$ B. Dziewanowski-Stefańczyk, Polityka monetarna..., s. 274. 
napisanej pod kier. U. Augustyniak, Warszawa 2012, Wydział Historyczny UW.

Dziewanowski-Stefańczyk B., Tytus Liwiusz Burattini jako dzierżawca mennic - ofiara czy winowajca kryzysu lat 1659-1668?, „Barok. Historia - literatura - sztuka" 33, 2010, nr 1, s. 67-96.

Gargas Z., Poglady ekonomiczne w Polsce w XVII wieku, Lwów 1903.

Lipiński E., Studia nad historia polskiej myśli ekonomicznej, Warszawa 1956. Popioł-Szymańska A., Poglady monetarne w Polsce od XV do XVIII wieku, Poznań 1978.

Rybarski R., Skarb i pieniadz za Jana Kazimierza, Michała Korybuta $i$ Jana III, Warszawa 1939.

Sadowski Z., Pieniadz a poczatki upadku Rzeczypospolitej w XVII w., Warszawa 1964.

Szelagowski A., Pieniadz i przewrót cen w XVI i XVII wieku, Lwów 1902.

Paweł Niziołek

The origin of the monetary crisis in Poland in the latter half of the seventeenth century in the opinions of the Polish nobility from the Kraków province (Summary)

In the years 1648-1696 the nobles from the Kraków province, as well as from the Duchy of Oświęcim and the Duchy of Zator, attending the regional assemblies (the so-called sejmiks) of the nobility held in Proszowice and Zator pointed to a number of sources of distortion of the money market. The way in which the issue was viewed by the Commonwealth's political class evolved in parallel with changes occurring in the money market. In the years 1648-1650 the nobles focused their attention on the domestic coin deficit, criticizing, in connection with the reform carried out in 1650, a half-hearted conduct of monetary policy. The problem of the foreigners, to whom mints were leased out and whom nobody supervised, dominated the debate in question shortly after the Swedish occupation of Kraków. However, it soon gave way to a number of issues concerning the emission of copper szelags (shillings) - the so-called "boratynkas" (from 1659) and zlotys (gold coins) the so-called "tymfs" (from 1663). The Polish nobility considered the crisis of Poland's monetary system to originate in the uncontrolled administration of mints by those who oversaw the emission of the two kinds of coins mentioned above, that is, by the Grand Treasurer of the Crown, parliamentary committees and senators. In the years 1661-1666, Polish nobles argued that domestic economy was also harmed by the circulation of foreign currency - Swedish shillings. With the mints shut down, their attention shifted to the harm done by the circulation of "boratynkas" and "tymfs" and by the prevalence of forgery. The Grand Treasurer of the Crown, Jan Kazimierz Krasiński, was the first to be blamed for issuing 
the coins and thus for provoking the crisis. The group of those held responsible for the crisis also included Tytus Liviusz Borattini, Andrzej and Tomasz Tymf, members of the Committee for Soldiers' Wage Payments, as well as a number of senators and superintendents. Although these persons were members of the royal faction, the transcripts of parliamentary debates demonstrate that the king himself, quite notably, was not criticized with regard to the crisis in question.

Key words: Polish nobility, regional aseemblies, coin, mint, monetary policy 